\title{
MASS MEDIA IN SHAPING A CHILD PERSONALITY IN THE EARLY SCHOOL AGE - A REVIEW OF SELECTED SITES
}

\section{Grzegorz, LUSZCZAK}

Abstract: The article refers to the problems of the media. The considerations presented in the context of the position of the child personality development in younger school age. Among other things refers to analysis of the concept and the concept of personality. Included are also the fundamental theoretical premises relating to the mass media ( that is an analysis of the terminological issues, functions and models ). In conclusion pointed out the risks that may negatively affect the student personality development in early school age.

Keywords: Behaviour, incentives, internet, mass - media, personality, television.

\section{MASS MEDIA W KSZTALTOWANIU OSOBOWOŚCI DZIECKA W WIEKU W CZESNOSZKOLNYM - PRZEGLAD WYBRANYCH STANOWISK}

Abstrakcyjny: W artykule odniesiono się do problematyki środków masowego przekazu. W rozważaniach zaprezentowano stanowisko w kontekście kształtowania osobowości dziecka w młodszym wieku szkolnym. Przedstawiono analizę pojęcia i zaprezentowano koncepcje osobowości. Uwzględnione zostały także fundamentalne przesłanki teoretyczne, odnoszące się do mass mediów ( terminologia zagadnienia, funkcje i modele ).W konkluzji wskazano na zagrożenia, które mogą negatywnie wpływać na rozwój osobowości ucznia w wieku wczesnoszkolnym.

Stowa kluczowe: Behawioryzm, bodźce, internet, mass - media, osobowość, telewizja.

\section{Introduction}

It was already said and written a lot about mass media. Many times this issue was raised in reference to different context. It was treated as a measure that could pose a treat to a child's development and, at the same time, enable to acquire new skills. The aim of this material is to present the personality from the psychological perspective and also to show the negative sides of mass media in the context of shaping early school children behaviour.

2. What is a personality? Few words about behavioural psychology and not only...

Psychology, similarly to anthropology, philosophy, pedagogic and sociology, constitutes a sphere of knowledge which a man deals with. A man aims at becoming acquainted with it in the physical, psychical and social aspect. It refers also to the fundamental approaches and attitudes, among which we differentiate:

- behaviorist approach,

- biological approach,

- evolutionary approach,

- cognitive approach,
- psychodynamic approach ${ }^{1}$.

Psychological literature more of ten refers to the issue and concept of personality. According to S. Gerstmann ${ }^{2}$ this notion is very often confused with word "psyche" or "mentality". Author believes that this notion can not be identified with the quoted issue. It is a term, which constitutes a fundament for behavioural sciences. Behaviourism refers not only to the study of a man but also to the social life phenomena. This trend has developed in the middle of the $20^{\text {th }}$ century. It was a dominant direction of psychoanalysis and psychology of a man. At the beginning of $21^{\text {st }}$ century it is not only used in the sphere of psychology but also is considered by scientists in pedagogic.

Personality, Latin persona, per sonare - is a term which was many times analysed by psychologists (behaviourists) and educators. This

\footnotetext{
1 J. Karbowniczek, Procesy poznawcze dzieci w wieku przedszkolnym, [ w:] Trvalo udržatel'ný rozvoj očami detí predškolského veku. Zborník z vedecko - odbornej konferencie s medzinárodnou účast’ou, Mária Podhájecká Monika Miňová ( eds. ), Presov 2010, p. 176.

2 S. Gerstmann, Psychologia, Warszawa 1969, p. 155.
} 
notion was referred by Z. Freud, E. Fromm, J. Formański, E. Guthrie, K. Horney, J. Reykowski, S. Siek and T. Tomaszewski. The definition of personality was first formulated by G. W. Allport in 1973. So far there are fifty interpretations of this notion divided into five groups analysed in reference to a biosocial, philosophical, legal, psychological and sociological context. According to J. Formański ${ }^{3}$ personality is a central system of a human actions and behaviours regulation. A. Beauvale ${ }^{4}$ believes that it is a theoretical structure, hypothetically explaining differences between people in the scope of a typical for a given individuals behaviours. A. Beauvale states that personality, depending on the theoretical attitude, refers to:

1. broader or narrower scope of behaviours (...),

2. direction/content of behaviour or formal characteristics (cohesion, intensity and efficiency) being the elements of personality,

In some theories - according to the author personality posses a status of a hypothetic existence, which is similar to the status of conscience, memory, individual and will. Other theories treat it as a psychological term, pointing out the character of an individual and especially psychical characteristics and the type of behaviour. A different approach is presented by a Polish educator

W. Okon ${ }^{5}$. According to the author, personality is a set of constant features and psychophysical processes, which differentiate given individual from other people (behaviour, experience, information and skills acquisition).

The question of personality is considered in four meanings. Authors point out that "persona" refers to:

- external appearance of a man,

- a role an individual plays in the society,

- people playing their role in a theological sense,

- individual skills.

What is a personality? It is a complex question. After a deep analysis we come to a conclusion that this notion refers not only to

3 J. Formański, Psychologia, Warszawa 2000, p. 112.

$4 \quad$ A. Beauvale, hasło : osobowość, [w:]

Słownik psychologii, ( red. ) J. Siuta, Kraków 2009, p. 173.

5 W. Okoń, Nowy Słownik pedagogiczny, Warszawa 1998, p. 278 humanism and interactionism, but also in the theories of: types (Hippocrates, W. H. Sheldon), features, psychodynamic, psychoanalytical ( $Z$. Freud, C. G. Jung) as well as social learning (A. Adler, E. Fromm, K. Horney).

More often scientists notice that factors which contribute to personality shaping are:

- anatomical and physiological features,

- family surrounding interaction,

- types of activities undertaken by an individual.

According to $\mathrm{T}$. Nowacki personality undoubtedly consists of (...) experiences determining views, attitudes and aims - life plan designed by a person itself ${ }^{6}$.

Literature shows that personality is not given to a human on the day he was born. It is being shaped by the influence of various interactions of an individual with other people as well as by the theory of social learning. The last factor constitutes an important link in psychology because it indicates reactions, which may change a man's behaviour in certain situations.

Nowadays we have many concepts of personality features. Among others, this term was used by S. Gerstmann, P. Guillaume, W. Łukaszewski, T. Nowacki and W. Szewczuk.

Authors refer mainly to the concept of G. W. Allport, J. P. Guilford and W. Stern.

G. W. Allport indicates the neurophysical system, which works out different stimuli. According to him it constitutes a fundament for adaptative and expressive behaviour of a human. G. W. Allport made a division of personality features. These features are:

a. common and individual - differentiating from the dominant features in a particular social and cultural groups,

b. central, cardinal (secondary) - expressed as a pillar of life's activity,

c. initiating adaptable and expressive

\section{behaviour.}

Similar to the G. W. Allport concept is the concept of W. Stern. This outstanding psychologist indicates 3 basic elements of the personality structure:

- symptoms (ideas, feelings, impressions and consciousness states)

- acts (among others: thinking, will, impulses)

- disposition (character, intelligence, temper and skills)

6 T. Nowacki, Elementy psychologii, Wrocław - Warszawa - Kraków - Gdańsk 1975, p. 392. 
Authors in their psychological works indicate also personality functions. They refer to:

a. integration/consolidation of all psychical processes,

b. regulation of relations between the man and the surrounding,

c. adjusting the individual to surrounding and implementation of changes.

In conclusion it should be pointed out that personality is a fundamental component. It contributes not only to the characteristic of a man, and also indicates its proper and unique features.

\section{Mass media in shaping the child personality in the early school age.}

The term mass media appeared for the first time in the 1940 's of the $20^{\text {th }}$ century in United States.

This notion have been formulated by many prominent psychologists and educators. W. Okoń and $\mathrm{Cz}$. Kapisiewicz were Polish didactic specialists who also worked on this topic. According to the first author, mass media are devices transferring specific message through indirect contacts. W. Okon ${ }^{7}$ includes in mass media, among other things: radio, television and press. Cz. Kapisiewicz ${ }^{8}$ presents this notion in a slightly different way. According to him mass media are means of social communication of a wide scope. Cz. Kapisiewicz includes in mass media: phonography, internet, press, radio, television. To summarise the foregoing there should be pointed out that the means of mass media by the use of pictures and sounds transfer message to the recipients. This process may be direct or indirect. In the first type the content of message is transferred directly to the recipient. It is done through the sender by an interpersonal contact. Indirect way consists in transferring the information with the use of sound, word and picture.

Mass media as a wide scope measures have specified functions:

- educational,

- informative,

- interpretative,

- cultural,

- entertaining,

$7 \quad$ W. Okoń, Nowy słownik pedagogiczny, Warszawa 1998, p. 392.

8 Cz. Kupisiewicz, M. Kupisiewicz, Słownik pedagogiczny, Warszawa 2009, p. 176.
- pedagogical.

According to W. Strykowski means of mass media posses three basic functions:

- emotional - motivational,

- active - interactive,

- cognitive - educational.

Nowadays we refer to the models showing the communication process. These are mainly western models. They constitute a fundament for functioning of media. J. Gajda ${ }^{9}$ indicates the following models:

- omnipotence of propaganda,

- persuasive act,

- diffusive,

- community of experiences,

- sociological,

- socially - cultural,

- linguistic.

M. Wolska - Długosz ${ }^{10}$ differentiates three types of the influence of mass media on personality:

a. direct - the most common among children;

directly after watching a program they react very vigorously, showing the states of their feelings; those states may be characterised by happiness or sadness, bravery or fear, activeness or withdrawal.,

b. cumulative - extended in time, at the beginning is almost imperceptible;

the process of influencing is divided into stages, where the previous one prepares the following; it is very often compared to a mosaic, in which the effect is visible in the last stage and after long time. A classical example of the cumulative influence is the result of multiple watching a film, which at the beginning evoked intense resistance and criticism and after few shows this negative opinion is noticeably softened or even gone. The phenomenon of multiple repeating softens the sharpness of stimuli received during the first show. This can be observed during watching aggressive films by young people. Many people goes through utmost criticisms to experiencing a kind of pleasure from watching such pictures.,

9 J. Gajda, Dominująca rola mass mediów i hipermediów w kulturze i edukacji, [w:] Edukacja medialna, red. J. Gajda, S. Juszczyk, B. Siemieniecki, K. Wenta, Torun 2002, p. $50-54$.

10 M. Wolska - Długosz, Wpływ reklamy na zachowanie się dzieci i młodzieży, Świętokrzyskie Centrum Edukacji na Odległość, „, Zeszyty Naukowe "2006, no 2, p. 328. 
c. subconscious - happens in an unintentional way; contents or pictures penetrates the psyche of

a man, being able to see only at the beginning of a process; it is characterised with a secrecy of action, with this end in view we search for the newest technologies leading to influence the individual as well as the whole society. Recognising them reduces or finishes their influence on a man's psyche.

"Mass media influence an individual by satisfying the cognitive necessity (collecting information and learning about world and explaining different problems and notions); affective (providing with new emotional and aesthetic experiences); personal integration (broadening contacts with other people in the society); reduction of tense (supplying with entertainment and allowing spending free time in a nice way). We may then assume that there are no doubts about the influence of mass media on the recipients, but the scope and the intensity of this influence may vary. There are two types of mass communication influence: direct reaction on opinions, attitudes, views and behaviours and indirect, which is more general, long-term and more difficult to notice. The influence of mass media means on an individual may show lack of the mass communication effect, which means such influence of the given communication which did not evoke any noticeable changes, or an opposite situation, in which the planned mass communication effects are achieved." ${ }^{11}$.

In the beginning of the $21^{\text {st }}$ century mass media play a significant role in the life of today's world. First of all they constitute some king of "goods" which to some extent serves people. In this way mass media means realise the employment and also stimulate other sectors to develop and act. It should be noticed that mass media construct the knowledge resources. They become a "life arena" in which many public and private affairs take place. More often children become interested in mass media which try not only to promote products but also to influence child's personality. Childhood is now dominated by radio, television and the internet. In many works, among others, in this of J. Izdebska ${ }^{12}$ it is

11 A. Podolski, Postawy, a mass media, [w:] Pol;ski system edukacji po reformie 1999 roku. Stan perspektywy zagrożenia, red. R. Pęczkowski, Poznań - Warszawa 2005, p. 139.

12 J. Izdebska, Dzieciństwo medialne współczesnych dzieci - teoretyczne i metodologiczne przesłanki badań, noticed that we deal with so called media childhood, which have been shaped by everyday presence in front of a tv and computer. Mass media means influence a child's behaviour through pictures, opinions and samples of behaviour. More then once they sound better than own parents. The contact of a child with mass media means can be observed from the very first years. Media intensively or even possessively can subordinate an individual. This way they enter into the sphere of life. It should be underlined that children are not conscious of all actions mass media undertake. They are being manipulated to do senseless actions. For example they demand buying some products after watching advertisements (like: Barbie doll, candies "Mars" etc.). "Parents reasons and arguments rectifying disinformation are not convincing enough in the view of the persuasive strength of an advertisement. Not understanding the mechanism used in an advertisement, not thinking about the intentional manipulation leads to a conflict between kids and adults. A result of this type of advertisements is the change of nutritional preferences and evoking of greediness. It takes effects in irrational eating between the meals or substituting normal, balanced dishes with products shown in advertisement. Many children are overweight as a natural result of such conditions."13

For early school age child mass media are an important and also a reliable mean of communication. They perceive radio, television and internet in an authentic way, and at the same time they aim is to identify with contents transferred through the mass media. Literature shows that what appeals to children is the world of colours, funny scenes or situational humour. These are the components, which impress a young spectator (deliver samples and models of behaviour). It should be pointed out that they influence a child's personality to a great extent. Evidence of this fact is given by different research statistics. Research done by A. Zając ${ }^{14}$

[w:] Dziecko w świecie wiedzy, informacji i komunikacji, red. S. Jusczyk, I. Polewczyk, Toruń 2006.

13 R. Wąs, Wpływ reklamy telewizyjnej na kształtowanie osobowości i postaw dzieci, http://www.edukacja.edux.pl/p-1931-wplyw-reklamytelewizyinej-na-ksztaltowanie.php , [ dostęp : 8.12.2010 ]

14 A. Zając, Wychowawcze aspekty filmów animowanych emitowanych przez polskojęzyczną 
shows that excessive TV programs watching may lead to sleeplessness, initiative and creativity loss and emotional disorders.

\section{Conclusions}

Nowadays means of mass media significantly influence a child's life. They have an effect on the cognitive processes and personality of a child. Researches taken up to date show that the danger comes mainly from television and internet. ${ }^{15}$ Above reflections present that mass media aim at: creating youth idols, which, as a result promotes the "worship of celebrities"; identifying with presented by famous actors behaviour;

- activating aggressive behaviour and violence in the family and school surrounding;

- promoting intolerance towards peers and adults;

promoting drugs and other stimulants, pornographic materials.

\section{Bibliography}

[1] Beauvale A., entry: osobowość, [w:] Słownik psychologii, ( red. ) J. Siuta, Kraków 2009, p. 173.

[2] Formański J., Psychologia, Warszawa 2000, p. 112.

[3] Gajda J., Dominująca rola mass mediów i hipermediów w kulturze i edukacji, [w:] Edukacja medialna, red. J. Gajda, S. Juszczyk, B. Siemieniecki, K. Wenta, Toruń 2002, p. 50 - 54.

[4] Gerstmann S., Psychologia, Warszawa 1969, p. 155 .

[5] Izdebska J., Dzieciństwo medialne współczesnych dzieci - teoretyczne i metodologiczne przesłanki badań, [w:] Dziecko w świecie wiedzy, informacji i komunikacji, red. S. Jusczyk, I. Polewczyk, Toruń 2006.

[6] Karbowniczek J., Procesy poznawcze dzieci w wieku przedszkolnym, [ w:] Trvalo udržatel'ný rozvoj očami detí predškolského veku. Zborník $\mathrm{z}$ vedecko - odbornej konferencie $\mathrm{s}$ medzinárodnou

účast’ou, Mária Podhájecká Monika Miňová ( eds. ), Presov 2010.

telewizję, [w:] Media w kulturze, nauce oświacie, red. W. Strykowski, A. Zając, Tarnów 1996, s. 113.

15 J. Karbowniczek, M. Grabowski, Kilka słów o oddziaływaniu Internetu na psychikę dzieci i młodzieży,

[w:] Wychowanie i nauczanie w społeczeństwie otwartym - wybrane zagadnienia, red. W. Grelowska, E.Kielska Radom 2010, p. 23 - 30.
[7] Karbowniczek J., Grabowski M., Kilka słów o oddziaływaniu Internetu na psychikę dzieci i młodzieży, [w:] Wychowanie i nauczanie w społeczeństwie otwartym - wybrane zagadnienia,

Radom 2010, p. 23 - 30.

[8] Kupisiewicz Cz., Kupisiewicz M., Słownik pedagogiczny, Warszawa 2009, p. 176.

[9] Nowacki T., Elementy psychologii, Wrocław - Warszawa - Kraków - Gdańsk 1975, p. 392.

[10] Okoń W., Nowy Słownik pedagogiczny, Warszawa 1998, p. 278, 392.

[11] Podolski A., Postawy, a mass media, [w:] Pol;ski system edukacji po reformie 1999 roku.

Stan perspektywy zagrożenia, red. R. Pęczkowski, Poznań - Warszawa 2005, p. 139.

[12] Wolska - Długosz M., Wpływ reklamy na zachowanie się dzieci i młodzieży, Świętokrzyskie Centrum Edukacji na Odległość, „Zeszyty Naukowe” 2006, nr 2, p. 328.

[13] A. Zając, Wychowawcze aspekty filmów animowanych emitowanych przez polskojęzyczną telewizję, [w:] Media w kulturze, nauce oświacie, red. W. Strykowski, A. Zając, Tarnów 1996, p. 113.

[14] R. Wąs, Wpływ reklamy telewizyjnej na kształtowanie osobowości i postaw dzieci, http://www.edukacja.edux.pl/p-1931-wplywreklamy-telewizyjnej-na-ksztaltowanie.php

\section{Dr Grzegorz Luszczak \\ IGNATIANUM University of Philosophy and Education in Krakow}

